\title{
PEMBELAJARAN BERBASIS MASALAH DENGAN MIND MAP UNTUK MENINGKATKAN PENGUASAAN KONSEP DAN KETERAMPILAN BERPIKIR KREATIF SISWA SMP PADA TEMA PENCEMARAN LINGKUNGAN
}

\author{
Ening Yuningsih ${ }^{1}$, Rita Retnowati ${ }^{2}$, Dadang Jaenudin ${ }^{2}$ \\ ${ }^{1}$ Program Studi Pendidikan IPA Sekolah Pascasarjana Universitas Pakuan \\ *E-mail: eningmh@gmail.com
}

\begin{abstract}
Abstrak: Penelitian ini bertujuan meningkatkan penguasaan konsep dan keterampilan berpikir kreatif siswa SMP pada materi Pencemaran Lingkungan melalui pembelajaran berbasis masalah dengan mind map. Metode yang digunakan yaitu kuasi eksperimen dengan pretest-postest control group design. Penelitian dilaksanakan di salah satu SMP Negeri Kabupaten Cianjur, dengan subjek penelitian berjumlah 67 orang dikelas kontrol dan eksperimen. Kelas eksperimen yaitu kelas VII E diberi perlakuan pembelajaran berbasis masalah dengan mind map dan kelas kontrol yaitu kelas VII D mendapat pembelajaran berbasis masalah. Instrumen yang digunakan berupa tes pilihan ganda (PG) untuk penguasaan konsep, Essay untuk kemampuan berpikir kreatif dan angket untuk melihat respon siswa. Data dianalisis dengan uji statistik menggunakan SPSS versi 24.00 dan analisis deskriptif. Hasil penelitian menunjukan bahwa pembelajaran berbasis masalah dengan mind map mampu meningkatkan penguasaan konsep dan keterampilan berpikir kreatif. Penguasaan konsep siswa dikelas eksperimen meningkat dengan nilai N-gain 0,62 (kriteria Sedang) dan meningkatkan keterampilan berpikir kreatif dengan nilai $\mathrm{N}$-gain 0,79 (kriteria tinggi). Siswa pada kelas eksperimen juga menunjukan respon dan antusias tinggi terhadap pembelajaran.
\end{abstract}

Kata Kunci: Pembelajaran berbasis Masalah, Mind Map, Penguasaan Konsep dan Keterampilan Berpikir Kreatif

\section{PENDAHULUAN}

Penguasaan konsep dalam proses pembelajaran, sangatlah penting. Seseorang dapat dikatakan menguasai konsep jika orang tersebut benar-benar memahami konsep yang dipelajarinya sehingga mampu menjelaskan dengan menggunakan kata-kata sendiri sesuai dengan pengetahuan yang dimilikinya, tetapi tidak mengubah makna yang ada di dalamnya. Melalui pembelajaran IPA, siswa dapat memperoleh pengalaman langsung, sehingga dapat menambah kekuatan untuk menerima, menyimpan, dan menerapkan konsep yang telah dipelajarinya. Dengan demikian, siswa terlatih untuk dapat menemukan sendiri berbagai konsep yang dipelajari secara menyeluruh (holistik) dan bermakna. 
Berdasarkan dari beberapa kompetensi yang perlu dikembangkan pada Kurikulum 2013 yaitu memahami fakta, konsep, prinsip atau hukum, dan teori yang menjelaskan serta memprediksi gejala alam hal ini sangat penting untuk penguasaan konsep siswa. Namun kenyataannya bahwa penguasaan konsep siswa masih rendah. Fakta ini terlihat dari hasil studi pendahuluan di salah satu sekolah di Kabupaten Cianjur bahwa siswa yang tuntas belajar hanya sebesar 29,41\% sedangkan yang belum tuntas $70,59 \%$. Data tersebut ini menunjukan bahwa masih banyak siswa yang belum tuntas.

Penguasaan konsep yang diperoleh di kelas VII semester 2 diantaranya, Sistem Organisasi Kehidupan sebesar 83,46 \%, Ekosistem sebesar 68,24\%, Pencemaran Lingkungan sebesar 36,40\%, Perubahan Iklim sebesar 38,24\% Lapisan Bumi dan Bencana sebesar 56,99\% dan Tata Surya sebesar 86,03\%. Ini menunjukan bahwa pada Materi pencearan Lingkungan memiliki penguasaan konsep yang paling rendah di bandingkan dengan materi lainnya. Hal ini mengindikasikan bahwa pemahaman yang dimiliki oleh siswa pada materi tersebut masih rendah, sehingga dalam melakukan perbaikan harus di fokuskan pada KD yang perolehannya masih kecil. Begitupun hasil wawancara dengan siswa yang menyatakan bahwa materi pada KD 7 memang sering kali terjadi dalam kehidupan sehari-hari namun siwa masih kesulitan menghubungkan kejadian sehari-hari dengan konsep dalam materi pembelajaran.

Senada dengan Trilling \& Fadel (2009) mengelompokkan keterampilan abad 21 dalam tiga kategori yaitu (1) Life and carrer skills, (2) Learning and innovation skills, dan (3) Information media dan technology skills. Keterampilan abad 21 fokus pada jenis keterampilan berpikir kompleks, keterampilan komunikasi, dan semua keterampilan yang lebih menuntut untuk mengajar dan belajar dibandingkan keterampilan hafalan. Salah satu keterampilan berfikir kompleks adalah berpikir kreatif. Dalam memahami suatu konsep, siswa tidak hanya dituntut untuk mengetahui dan mengingat saja, tetapi harus melibatkan kemampuan berpikir, salah satunya adalah kemampuan berpikir kreatif. Namun kenyataannya pengembangan pengajaran di sekolah pada umumnya hanya terbatas pada penalaran verbal dan pemikiran logis, pada tugas-tugas yang hanya membuat pemikiran konvergen yaitu pemikiran menuju satu jawaban.

Berdasarkan fenomena dan pendapat diatas muncul pertanyaan metode, pendekatan atau strategi apa yang sesuai dengan karakteristik siswa agar memperoleh penguasaan konsep dan kemampuan berpikir kreatif yang baik yang mengangkat permasalahan dalam kehidupan sehari-hari dan membuat pembelajaran IPA menjadi menyenangkan. Salah satu model pembelajaran yang diharapkan sesuai adalah Pembelajaran berbasis Masalah atau Problem Base Learning (PBL). Hal ini dikarenakan pembelajaran berbasis masalah dapat menjembatani gap antara pembelajaran di sekolah formal dengan aktivitas mental 
yang di jumpai di luar sekolah. Pembelajaran Berbasis Masalah merupakan pembelajaran yang berpusat pada siswa., siswa dapat menentukan sendiri apa yang harus dipelajari, siswa dapat menyelesaikan permasalahannya, dan guru hanya sebagai pembimbing atau fasilitator.

Materi pembelajaran bisa dipetakan dalam bentuk peta pemikiran, mulai dari tema besar di tengah halaman, menggunakan kata-kata penting, menggunakan simbol, warna, kata, gambar yang mencolok, dan ini dapat dilakukan dengan gaya atau keinginan siswa sendiri. Dalam mencatat pelajaran, gunakan tanda-tanda, gambar dan warna untuk menandai hal-hal penting agar dapat dengan mudah dilihat lagi jika kita mempelajarinya di lain waktu. Para peneliti menegaskan bahwa presentasi visual adalah hal penting bagi siswa untuk memahami pengetahuan baru. Mona \& Khalick (dalam Long dan Carlson, 2011) menyatakan bahwa peta pemikiran merupakan salah satu alat presentasi visual yang berguna untuk membantu siswa dalam proses membangun pemahaman konseptual terhadap konten dan peningkatan hasil belajar. Lawson (dalam Adodo, 2013) menyatakan bahwa konsep mind map adalah metode yang dapat memvisualisasikan struktur pengetahuan. Representasi visual juga memungkinkan pengembangan pemahaman holistik karena kata-kata saja tidak dapat menyampaikan secara sepenuhnya, dan dalam bentuk grafik memungkinkan keseluruhan representsi bagian yang tidak tersedia pada teks saja. Dengan menggunakan mind map (Dhindsa, 2010) membantu siswa memperkaya pemahaman terutama untuk yang lebih kompleks atau konten ilmiah abstrak.

Berdasarkan permasalahan diatas maka dilakukan penelitian yang mencoba untuk menggabungkan model pembelajaran berbasis masalah dengan mind map dan melihat pengaruhnya terhadap penguasaan konsep dan kemampuan berpikir kreatif siswa. Berdasarkan hal-hal tersebut penulis tertarik untuk melakukan penelitian tentang "Pembelajaran Berbasis Masalah dengan Mind Map untuk Meningkatkan Penguasaan Konsep dan Kemampuan Berpikir Kreatif Siswa SMP pada Tema Pencemaran Lingkungan"

\section{METODE}

Metode yang digunakan dalam penelitian ini adalah penelitian kuasi eksperimen (quasi experimental reseach). Desain penelitian yang digunakan adalah pretest-posttes control group design. Penelitian diawali dengan memilih kelompok untuk kelompok eksperimen dan kelompok kontrol (Fraenkel \& Wallen, 2008). Kelas eksperimen pembelajarannya menggunakan model pembelajaran berbasis masalah dengan mind map sedangkan kelas kontrol pembelajarannya menggunakan model pembelajaran berbasis masalah. Terhadap dua kelompok dilakukan pretest dan posttest untuk melihat penguasaan konsep dan kemampuan 
berpikir kreatif sebelum dan setelah di terapkan model pembelajaran. Desain penelitian uji coba produk ditunjukkan dalam tabel 1.

Tabel 1. Desain Penelitian

\begin{tabular}{lccc}
\hline \multicolumn{1}{c}{ Kelompok } & Pretest & Perlakuan & Posttest \\
\hline Eksperimen & $\mathrm{T}_{1}$ & $\mathrm{X}$ & $\mathrm{T}_{2}$ \\
\hline Kontrol & $\mathrm{T}_{1}$ & $\mathrm{Y}$ & $\mathrm{T}_{2}$ \\
\hline
\end{tabular}

Keterangan :

$\mathrm{T}_{1}=$ Pretest

$\mathrm{X}=$ Pembelajaran Berbasis Masalah dengan mind map

$\mathrm{Y}=$ Pembelajaran Berbasis masalah

$\mathrm{T}_{2}=$ Posttest

Subjek dalam Penelitian ini adalah siswa Kelas VII SMP Negeri 3 Karangtengah Cianjur Tahun Pelajaran 2017/2018 pada materi Pencemaran Lingkungan. Penelitian akan dilaksanakan di kelas VII D dengan jumlah 33 siswa sebagai kelas kontrol (kelas yang menggunakan pembelajaran berbasis masalah) dan kelas VII E dengan jumlah 34 siswa sebagai kelas Eksperimen (kelas yang menggunakan pembelajaran berbasis masalah dengan mind map). Sekolah tidak mengelompokkan kelasnya berdasarkan tingkat kemampuan (tidak ada kelas unggulan), dengan kata lain penyebaran siswa di sekolah ini heterogen sehingga dapat mewakili siswa dari tingkat kemampuan tinggi, sedang dan rendah.

\section{HASIL DAN PEMBAHASAN}

\section{Hasil}

\section{Penguasaan Konsep}

Data penguasaan konsep siswa kelas eksperimen dan kelas kontrol diperoleh dari hasil pretes-postes kemudian dianalisis dan diperoleh gambaran karakteristik data hasil pengolahan statistik disajikan pada Tabel 2.

Tabel 2. Penguasaan Konsep

\begin{tabular}{|c|c|c|c|c|c|}
\hline \multirow[b]{2}{*}{ Kelas } & \multirow[b]{2}{*}{$\begin{array}{l}\text { Parameter } \\
\text { statistik }\end{array}$} & \multicolumn{2}{|c|}{ Nilai } & \multirow[b]{2}{*}{$\begin{array}{l}\mathrm{N}- \\
\text { gain }\end{array}$} & \multirow[b]{2}{*}{ Kategor } \\
\hline & & $\begin{array}{l}\text { Pre } \\
\text { tes }\end{array}$ & $\begin{array}{l}\text { Pos } \\
\text { tes }\end{array}$ & & \\
\hline \multirow{2}{*}{ eksperimen } & Jumlah siswa & 34 & 34 & \multirow{2}{*}{0,62} & \multirow{2}{*}{ Sedang } \\
\hline & Rata-rata & 17 & 50 & & \\
\hline \multirow[b]{2}{*}{ Kontrol } & Jumlah siswa & 33 & 33 & \multirow[b]{2}{*}{0,52} & \multirow[b]{2}{*}{ Sedang } \\
\hline & Rata-rata & 17 & 43 & & \\
\hline
\end{tabular}


Tabel 2 memperlihatkan bahwa rata-rata nilai kemampuan awal penguasaan konsep siswa yang menggunakan model pembelajaran berbasis masalah dengan mind map hampir sama besar dengan pembelajaran berbasis masalah. Setelah pembelajaran dilaksanakan, rata-rata nilai postes penguasaan konsep menunjukkan bahwa nilai rata-rata eksperimen lebih tinggi jika dibandingkan dengan kelas kontrol, perbedaan rata-ratanya adalah sekitar 7,48. Hal ini menggambarkan bahwa nilai rata-rata penguasaan konsep yang menggunakan pembelajaran berbasis masalah dengan mind map lebih besar jika dibandingkan dengan model pembelajaran berbasis masalah.

Untuk rata-rata peningkatan penguasaan konsep (N-Gain penguasaan konsep), menunjukkan bahwa nilai rata-rata eksperimen yaitu 0,62 lebih tinggi jika dibandingkan dengan kelas kontrol yaitu 0,52 , perbedaan rata-ratanya adalah sekitar 0,10 . Hal ini menggambarkan bahwa skor rata-rata penguasaan konsep yang menggunakan model pembelajaran berbasis maslah dengan mind map lebih besar jika dibandingkan dengan model pembelajaran berbasis masalah.

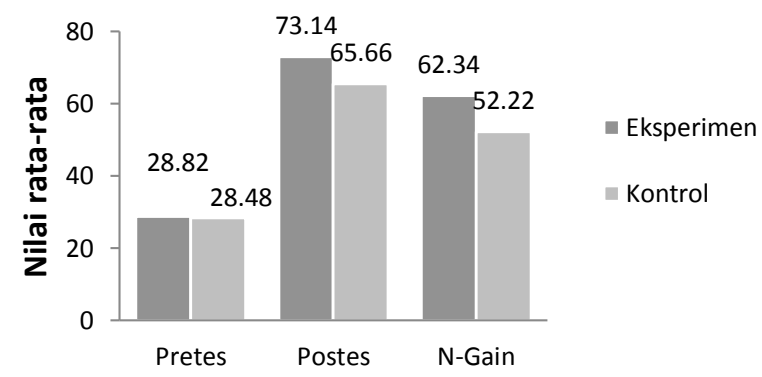

Gambar 1. Perolehan Nilai Rata-Rata Pretes, Postes Dan N-Gain Penguasaan Konsep

Berdasarkan Gambar 1 menunjukan rata-rata N-Gain yang dinormalisasi kelas eksperimen sebesar 62,34 sedangkan kelas kontrol sebesar 52,22. Hal tersebut di atas menunjukan bahwa ada perbedaan peningkatan penguasaan konsep pada tema pencemaran lingkungan yang menggunakan pembelajaran berbasis masalah dengan mind map dengan siswa yang menggunakan pembelajaran berbasis masalah.

Analisis data mengenai penguasaan konsep untuk setiap indikatornya di kelas eksperimen dapat dilihat pada Tabel 3. 
Tabel 3. Rata-Rata Pretest, Postest Dan N-Gain Untuk Setiap Jenjang Kognitif Penguasaan Konsep Siswa Kelas Eksperimen

\begin{tabular}{|c|c|c|c|c|}
\hline \multirow{2}{*}{$\begin{array}{l}\text { Jenjang } \\
\text { Kognitif }\end{array}$} & \multicolumn{2}{|c|}{ Rerata } & \multirow{2}{*}{ N-Gain } & \multirow{2}{*}{ Kategori } \\
\hline & pretest & postest & & \\
\hline $\mathrm{C} 1$ & 36,27 & 88,72 & 0,82 & Tinggi \\
\hline $\mathrm{C} 2$ & 30,25 & 80,46 & 0,72 & Tinggi \\
\hline C3 & 29,41 & 54,9 & 0,36 & Sedang \\
\hline $\mathrm{C} 4$ & 20,58 & 51,47 & 0,39 & Sedang \\
\hline
\end{tabular}

Selanjutnya untuk perolehan rata-rata pretest dan postest setiap indikator pada kelas kontrol dapat dilihat pada Tabel 4.

Tabel 4. Rata-Rata Pretest, Postest Dan N-Gain Untuk Setiap Jenjang Kognitif Penguasaan Konsep Siswa Kelas Kontrol.

\begin{tabular}{|c|c|c|c|c|}
\hline \multirow{2}{*}{$\begin{array}{l}\text { Jenjang } \\
\text { Kognitif }\end{array}$} & \multicolumn{2}{|c|}{ Rerata } & \multirow{2}{*}{ N-Gain } & \multirow{2}{*}{ Kategori } \\
\hline & pretest & postest & & \\
\hline $\mathrm{C} 1$ & 51,51 & 80,8 & 0,60 & Sedang \\
\hline $\mathrm{C} 2$ & 32,03 & 75,54 & 0,64 & Sedang \\
\hline C3 & 10,61 & 42,93 & 0,36 & Sedang \\
\hline $\mathrm{C} 4$ & 8,33 & 31,82 & 0,26 & Rendah \\
\hline
\end{tabular}

Tabel 4. menunjukan bahwa nilai rata-rata postest untuk setiap indikatornya lebih tinggi daripada nilai rata-rata pretesttnya. Perbandingan peningkatan nilai rata-rata pretest dan postest penguasaan konsep setiap indikator pada siswa kelas eksperimen dan kelas kontrol dapat dilihat dari N-Gain seperti ditunjukan pada Gambar 2 berikut.

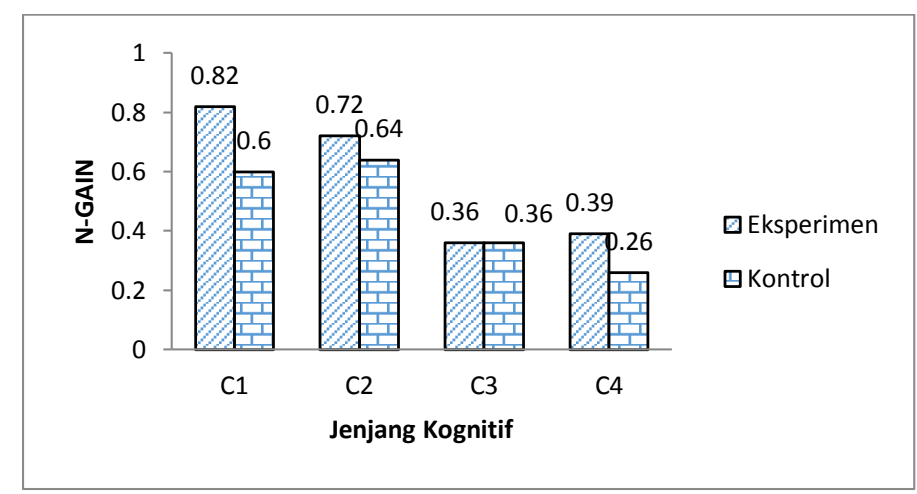

Gambar 2. N-Gain Penguasaan Konsep Setiap Indikator Pada Siswa Kelas Eksperimen Dan Kelas Kontrol 
Gambar 2. menunjukan bahwa N-Gain kelas eksperimen pada jenjang C1, C2 dan C4 lebih tinggi daripada kelas control, sedangkan pada jenjang C3 mempunyai N-Gain yang sama besar.

\section{a. Hasil Uji Normalitas}

Data penguasaan konsep pada masing-masing kelas dianalisis dengan menggunakan bantuan SPSS 24. Uji normalitas menggunakan one sample Kolmogorov-smirnov test, dalam uji normalitas menunjukan bahwa hasil uji normalitas $\mathrm{N}$-Gain penguasaan konsep siswa kelas eksperimen dan kelas kontrol diperoleh pada taraf signifikan >0,05, maka $\mathrm{H}_{\mathrm{o}}$ diterima. Dengan demikian dapat disimpulkan bahwa penguasaan konsep siswa berdistribusi normal. (Tabel 3).

\section{b. Hasil Uji Homogenitas}

Uji homogenitas dilakukan untuk melihat apakah data homogen atau tidak. Data penelitian diuji homogenitasnya dengan menggunakan Levene Tes (Tes of Homogenity of Varians) dengan menggunakan program SPSS 24. Adapun kriteria pengujian statistik data yaitu apabila nilai signifikasi ( $\mathrm{sig}$ ) > 0,05 maka $\mathrm{H}_{\mathrm{o}}$ diterima artinya data memiliki varians yang sama atau bersifat homogen. Tabel 3 . menunjukan bahwa hasil uji homogenitas Gain penguasaan konsep kelas eksperimen dan kelas kontrol diperoleh taraf signifikan >0,05. Dengan demikian dapat disimpulkan bahwa penguasaan konsep varians kedua sampel berdistribusi homogen.

\section{c. Hasil Uji Hipotesis}

Berdasarkan uji normalitas dan homogenitas yang telah dilakukan terhadap data penguasaan konsep diperoleh bahwa data berdistribusi normal dan homogen sehingga pengujian hipotesis dapat dilakukan dengan menggunakan uji Independent Sampel Test melalui bantuan SPSS 24. Adapun kriteria statistinya apabila nilai signifikan ( $\mathrm{sig}$ ) $<0,05$ maka $\mathrm{H}_{0}$ ditolak. Hasil uji hipotesis Gain penguasaan konsep kelas eksperimen dan kelas kontrol dapat dilihat pada Tabel 3. yang menunjukan bahwa nilai signifikasi yang diperoleh dari Gain penguasaan konsep kelas eksperimen dan kelas kontrol menujukan taraf sig $<0,05$ hal ini berarti $\mathrm{H}_{\mathrm{o}}$ ditolak sehingga terdapat perbedaan secara signifikan penguasaan konsep antara kelas eksperimen dengan kelas kontrol. Nilai Sig. (2-tailed) sebesar 0,020 untuk Sig. (1-tailed) $=\frac{1}{2} \times$ Sig. (2-tailed) atau $\frac{1}{2} \times 0,020=0,010$ yang berarti nilai signifikansinya lebih kecil daripada $\alpha=0,05$. Jadi, Ho ditolak, artinya kesimpulan peningkatan penguasaan konsep siswa yang pembelajarannya menggunakan model pembelajaran berbasis masalah dengan mind map lebih baik secara signifikan daripada yang menggunakan pembelajaran berbasis masalah. 
Tabel 5. Rekapitulasi Uji Normalitas, Uji Homogenitas dan Uji t N-gain Penguasaan Konsep

\begin{tabular}{|c|c|c|c|c|c|c|c|}
\hline \multirow{2}{*}{ Kelas } & \multirow{2}{*}{$\mathrm{N}$} & \multicolumn{2}{|c|}{ Uji normalitas } & \multicolumn{2}{|c|}{$\begin{array}{c}\text { Uji } \\
\text { homogenitas }\end{array}$} & \multicolumn{2}{|c|}{$\begin{array}{l}\text { Uji t (2-tailed) } \\
\text { (sig) }\end{array}$} \\
\hline & & $\begin{array}{l}\mathrm{Ni} \\
\text { lai }\end{array}$ & Ket & Nilai & Ket & Nilai & $\begin{array}{c}\text { Keteranga } \\
n\end{array}$ \\
\hline $\begin{array}{c}\text { Eks } \\
\text { perimen }\end{array}$ & 34 & 0,200 & \multirow{2}{*}{$\begin{array}{l}\text { Nor } \\
\text { mal }\end{array}$} & \multirow[t]{2}{*}{0,683} & \multirow{2}{*}{$\begin{array}{c}\text { Homo } \\
\text { gen }\end{array}$} & \multirow[t]{2}{*}{0,020} & \multirow[t]{2}{*}{ Signifikan } \\
\hline Kontrol & 33 & 0,200 & & & & & \\
\hline
\end{tabular}

\section{Keterampilan Berpikir Kreatif}

Data kemampuan berpikir kreatif siswa kelas eksperimen dan kelas kontrol diperoleh dari hasil pretes-postes kemudian dianalisa dan diperoleh gambaran karakteristik data meliputi rata-rata nilai, standar deviasi, nilai maksimal, nilai minimal dan jumlah siswa. Keseluruhan data hasil pengolahan statistik disajikan pada Tabel 6.

Tabel 6. Keterampilan Berpikir Kreatif

\begin{tabular}{ccccccc}
\hline \multirow{2}{*}{ Kelas } & \multirow{2}{*}{$\begin{array}{c}\text { Parameter } \\
\text { statistik }\end{array}$} & $\begin{array}{c}\text { Pre } \\
\text { Tes }\end{array}$ & $\begin{array}{c}\text { Pos } \\
\text { tes }\end{array}$ & \multirow{2}{*}{ N-gain } & Kategori \\
\cline { 2 - 4 } Eksperimen & Jumlah siswa & 34 & 34 & & \\
\cline { 2 - 4 } & Rata-rata & 30,70 & 84,93 & & \\
& \multirow{2}{*}{ Kontrol } & Jumlah siswa & 33 & 33 & & Tinggi \\
\cline { 2 - 4 } & Rata-rata & 29,26 & 78,50 & 0,70 & Sedang \\
\hline
\end{tabular}

Tabel 6 memperlihatkan bahwa rata-rata nilai kemampuan awal keterampilan berpikir kreatif siswa yang menggunakan model pembelajaran berbasis masalah dengan mind map lebih besar jika dibandingkan dengan pembelajaran berbasis masalah, perbedaannya sekitar 1,44. Setelah pembelajaran dilaksanakan, rata-rata skor postes keterampilan berpikir kreatif menunjukkan bahwa nilai rata-rata eksperimen lebih tinggi jika dibandingkan dengan kelas kontrol, perbedaan rataratanya adalah sekitar 6,43. Hal ini menggambarkan bahwa nilai rata-rata keterampilan berpikir kreatif yang menggunakan model pembelajaran berbasis masalah dengan mind map lebih besar jika dibandingkan dengan pembelajaran berbasis masalah.

Untuk rataan peningkatan keterampilan berpikir kreatif (N-Gain keterampilan berpikir kreatif), menunjukkan bahwa nilai rataan eksperimen yaitu 0,7918 lebih tinggi jika dibandingkan dengan kelas kontrol yaitu 0,7067, perbedaan rataannya adalah sekitar 0,085 . Hal ini menggambarkan bahwa nilai rataan 
keteampilan berpikir kreatif yang menggunakan model pembelajaran berbasis masalah dengan mind map lebih besar jika dibandingkan dengan model pembelajaran berbasis masalah.

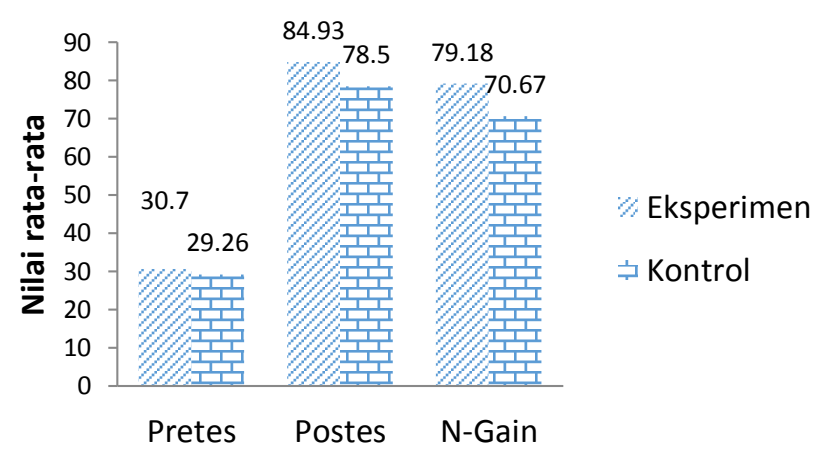

Gambar 3. Perolehan Nilai Rata-rata Pretes, Postes dan N-Gain Kemampuan Berpikir Kreatif Kelas Eksperimen dan Kelas Kontrol

Berdasarkan gambar 2 menunjukan peresentase rata-rata $\mathrm{N}$-Gain yang dinormalisasi kelas eksperimen sebesar 79,18 sedangkan kelas kontrol sebesar 70,67. Hal tersebut diatas menunjukan bahwa ada peningkatan kemampuan berpikir kreatif siswa pada materi pencemaran lingkungan yang menggunakan pembelajaran berbasis masalah dengan mind map dengan siswa yang menggunakan pembelajaran berbasis masalah.

Tabel 7. Rata-Rata Pretest, Postest Dan N-Gain Untuk Setiap Indikator Keterampilan Berpikir Kreatif siswa Kelas Eksperimen

\begin{tabular}{ccccc}
\hline \multirow{2}{*}{ Jenjang Kognitif } & \multicolumn{2}{c}{ Rerata } & \multirow{2}{N}{ N- } & \multirow{2}{*}{ Kategori } \\
\cline { 2 - 3 } & pretest & Postest & Gain & \\
\hline $\begin{array}{c}\text { Keterampilan berpikir orisinal } \\
\text { (Originality) }\end{array}$ & 33,45 & 84,19 & 0,76 & \multirow{2}{*}{ Tinggi } \\
\hline Keterampilan berfikir lancar (fluency) & 32,72 & 83,82 & 0,76 & Tinggi \\
\hline Keterampilan berfikir luwes (flexibility) & 30,14 & 85,29 & 0,79 & Tinggi \\
\hline Keterampilan menguraikan (elaboration) & 28,31 & 83,45 & 0,77 & Tinggi \\
\hline Keterampilan menilai (evaluation) & 26,47 & 91,17 & 0,88 & Tinggi \\
\hline
\end{tabular}

Tabel 7. menunjukan bahwa rata-rata postest untuk setiap indikator keterampilan berpikir kreatif di kelas eksperimen lebih tinggi daripada nilai ratarata pretestnya. Selanjutnya untuk perolehan rata-rata pretest dan posttest setiap indikator keterampilan berpikir kreatif pada kelas kontrol dapat dilihat pada Tabel 8. 
Tabel 8. Rata-Rata Pretest, Postest Dan N-Gain Untuk Setiap Indikator Keterampilan Berpikir Kreatif Siswa Kelas Kontrol.

\begin{tabular}{ccccc}
\hline \multirow{2}{*}{ Jenjang } & \multicolumn{2}{c}{ Rerata } & \multirow{2}{*}{ N-Gain } & \multirow{2}{*}{ Kategori } \\
\cline { 2 - 3 } Kognitif & pretest & Postest & & \\
\hline (Originality) & 30,3 & 77,65 & 0,68 & Sedang \\
\hline (fluency) & 27,65 & 76,51 & 0,68 & Sedang \\
\hline (flexibility) & 31,06 & 79,54 & 0,70 & Sedang \\
\hline (elaboration) & 23,48 & 72,73 & 0,64 & Sedang \\
\hline (evaluation) & 40,15 & 88,64 & 0,81 & Tinggi \\
\hline
\end{tabular}

Tabel 8. menunjukan bahwa nilai rata-rata postest untuk setiap indikatornya lebih tinggi daripada nilai rata-rata pretestnya. Perbandingan peningkatan nilai ratarata pretest dan postest keterampilan berpikir kreatif setiap indikator pada siswa kelas eksperimen dan kelas kontrol dapat dilihat dari N-Gain seperti ditunjukan pada Gambar 4 berikut.

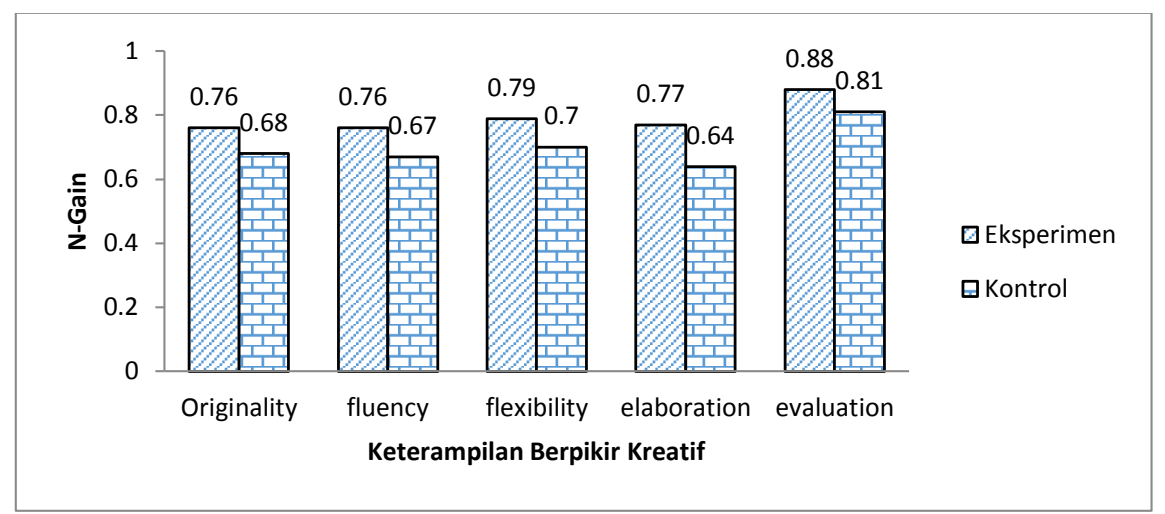

Gambar 4. N-Gain Keterampilan Berpikir Kreatif Setiap Indikator Pada Siswa Kelas Eksperimen Dan Kelas Kontrol

Gambar 4. menunjukan bahwa N-Gain kelas eksperimen pada setiap indikator keterampilan berpikir kreatif lebih tinggi daripada kelas kontrol.

\section{a. Hasil Uji Normalitas}

Data kemampuan berpikir kreatif pada masing-masing kelas dianalisis dengan menggunakan bantuan SPSS 24. Uji normalitas menggunakan one sample Kolmogorov-smirnov test. Hasil uji normalitas pada masing-masing kelas sampel dapat dilihat pada Tabel 5. Tabel 5 menunjukan bahwa hasil uji normalitas Gain kemampuan berpikir kreatif siswa kelas eksperimen dan kelas kontrol diperoleh pada taraf signifikan $>0,05$, maka $\mathrm{H}_{\mathrm{o}}$ diterima. Dengan demikian dapat disimpulkan bahwa kemampuan berpikir kreatif siswa berdistribusi normal. 


\section{b. Hasil Uji Homogenitas}

Uji homogenitas dilakukan untuk melihat apakah data homogen atau tidak. Data penelitian diuji homogenitasnya dengan menggunakan Levene Tes (Tes of Homogenity of Varians) dengan menggunakan program SPSS 24. Adapun kriteria pengujian statistik data yaitu apabila nilai signifikasi ( $\mathrm{sig}$ ) >0,05 maka $\mathrm{H}_{\mathrm{o}}$ diterima artinya data memiliki varians yang sama atau bersifat homogen. Tabel 5 menunjukan bahwa hasil uji homogenitas Gain kemampuan berpikir kreatif siswa kelas eksperimen dan kelas kontrol diperoleh taraf signifikan >0,05. Dengan demikian dapat disimpulkan bahwa kemampuan berpikir kreatif siswa varians kedua sampel berdistribusi homogen.

\section{c. Hasil Uji Hipotesis}

Berdasarkan uji normalitas dan homogenitas yang telah dilakukan terhadap data kemampuan berpikir kreatif diperoleh bahwa data berdistribusi normal dan homogen sehingga pengujian hipotesis dapat dilakukan dengan menggunakan uji Independent Sampel Test melalui bantuan SPSS 24. Adapun kriteria statistiknya apabila nilai signifikan ( $\mathrm{sig}$ ) $<0,05$ maka $\mathrm{H}_{0}$ ditolak. Berikut disajikan hasil uji hipotesis kemampuan berpikir kreatif siswa kelas eksperimen dan kelas kontrol dapat dilihat pada Tabel 5. Tabel 5. menunjukan bahwa nilai signifikasi yang diperoleh dari Gain kemampuan berpikir kreatif siswa kelas eksperimen dan kelas kontrol menujukan taraf sig $<0,05$ hal ini berarti $\mathrm{H}_{\mathrm{o}}$ ditolak sehingga terdapat perbedaan secara signifikan kemampuan berpikir kreatif antara kelas eksperimen dengan kelas kontrol.

Tabel 9. Rekapitulasi Uji Normalitas, Uji Homogenitas dan Uji t Kemampuan Berpikir Kreatif

\begin{tabular}{ccccccc}
\hline \multirow{2}{*}{ Kelas } & \multicolumn{2}{c}{ Uji normalitas } & Uji homogenitas & \multicolumn{2}{c}{$\begin{array}{c}\text { Uji t (2-tailed) } \\
\text { (sig) }\end{array}$} \\
\cline { 2 - 6 } & Nilai & Ket & Nilai & Ket & Nilai & Ket \\
\hline Eksperimen & 0,200 & $\begin{array}{c}\text { Nor } \\
\text { mal }\end{array}$ & 0,072 & homogen & 0,013 & Signifikan \\
\hline Kontrol & 0,167 & & & & & \\
\hline
\end{tabular}

Dari Tabel 9. di atas dapat dilihat bahwa nilai Sig. (2-tailed) sebesar 0,013 untuk Sig. (1-tailed) $=\frac{1}{2}$ x Sig. (2-tailed) atau $\frac{1}{2} \mathrm{x} 0,013=0,0065$ yang berarti nilai signifikansinya lebih kecil daripada $\alpha=0,05$. Jadi, Ho ditolak, artinya kesimpulan peningkatan keterampilan berpikir kreatif siswa yang pembelajarannya menggunakan model pembelajaran berbasis masalah dengan mind map lebih baik secara signifikan daripada yang menggunakan pembelajaran berbasis masalah. 


\section{Hasil Analisis Angket Tanggapan Siswa}

Tanggapan siswa dapat dilihat pada data yang diperoleh dari pemberian kuesioner tentang penerapan pembelajaran berbasis masalah dengan mind map. Grafik hasil tanggapan siswa terhadap penerapan pembelajaran berbasis masalah pada kelas eksperimen dapat ditunjukan pada Gambar 5. berikut

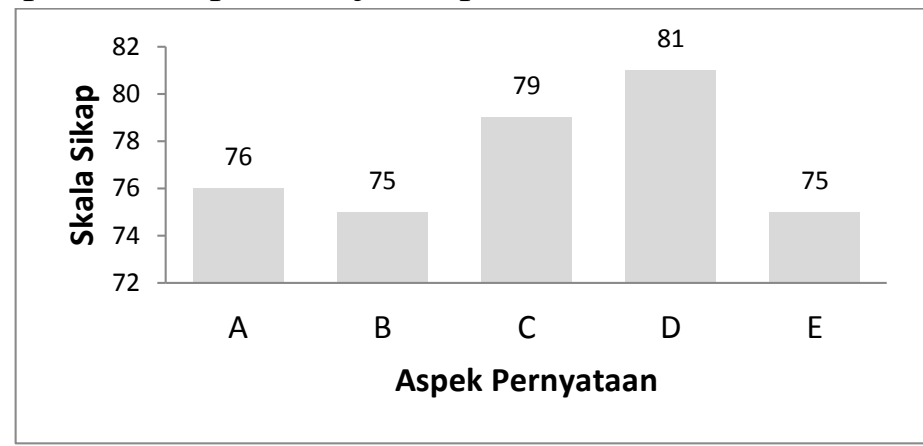

Gambar 5. Tanggapan Siswa Terhadap Pembelajaran Berbasis Masalah dengan Mind Map

Keterangan :

A = Sikap siswa terhadap Pembelajaran

B = Tanggapan siswa terhadap materi pembelajaran

$\mathbf{C}=$ Tanggapan siswa terhadap penguasaan konsep

D = Tanggapan siswa terhadap kreativitas

$\mathbf{E}=$ Tanggapan terhadap penggunaan mind map dalam pembelajaran

Gambar 5. menunjukkan perbandingan persentase masing-masing tanggapan siswa yang beragam tetapi persentase tertinggi sekitar $81 \%$ siswa dikelas eksperimen memberikan respon positif dan sangat senang dengan pembelajaran berbasis masalah dengan mind map yang dapat meningkatkan kreativitas.

\section{Hasil Kreativitas Mind Map}

Kreativitas dijaring melalui mind map yang dibuat siswa yang pembelajarannya menggunakan pembelajaran berbasis masalah dengan mind map. Indikator kreativitas yang dianalisis meliputi kemampuan berpikir asli (originality), berpikir lancar (Fluency), dan kemampuan berpikir memerinci (Elaboration). Penilaian mind map siswa pada kelas eksperimen seperti ditunjukan pada gambar 6. 


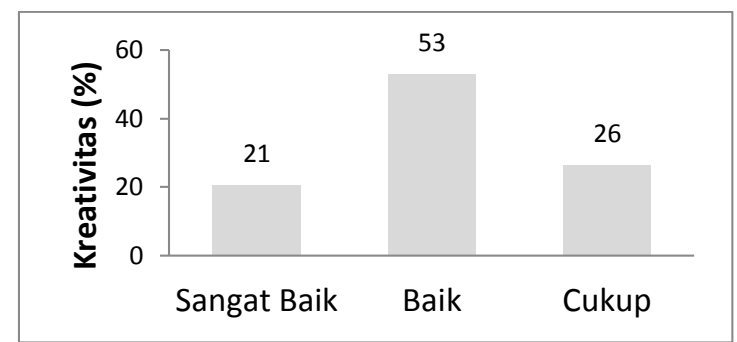

Gambar 5. Nilai Kreativitas Siswa Kelas Ekperimen

\section{Pembahasan}

Berdasarkan hasil penelitian pada tema pencemaran lingkungan dengan menggunakan model pembelajaran berbasis masalah dengan Mind Map dapat meningkatkan penguasaan konsep dan keterampilan berpikir kreatif. Penelitian ini terdapat dua kelompok siswa yang berbeda dan memperoleh perlakuan yang berbeda.

Data yang didapat dari penelitian ini berupa data kuantitatif hasil belajar siswa dari nilai pretest dan postest. Soal yang diberikan berupa soal pilihan ganda untuk soal penguasaan konsep dan essay untuk soal kemampuan berpikir kreatif. Pretest dilaksanakan sebelum diberikan perlakuan, pada siswa kontrol dan siswa eksperimen yang bertujuan untuk melihat kemampuan awal siswa pada kedua kelas tersebut. Setelah diberikan perlakuan pada kedua kelas tersebut dilakukan postest dengan soal yang sama. Postest dilakukan untuk mengetahui kemampuan penguasaan konsep dan keterampilan berpikir kreatif siswa setelah diberikan perlakuan.

Berdasarkan pada Gambar 1. diketahui bahwa terjadi peningkatan penguasaan konsep siswa pada masing-masing kelas sampel, yaitu kelas kontrol dan kelas eksperimen. Oleh karena itu, dapat dikatakan bahwa pada masing-masing kelas, penguasaan konsep siswa pada postest lebih baik dari pretest. Tingkat peningkatan penguasaan konsep siswa tersebut dapat dilihat berdasarkan N-Gain yang diperoleh. Pada kelas eksperimen diperoleh N-Gain 0,62 (kategori sedang) sedangkan pada kelas kontrol diperoleh N-Gain 0,52 (kategori sedang). Adapun hasil dari uji signifikansi beda rata-rata skor postes penguasaan konsep pada kelas eksperimen dan kelas kontrol menunjukan perbedaan yang signifikan.

Model pembelajaran berbasis masalah dengan mind map menuntut siswa untuk aktif memecahkan masalah, peserta didik akan mengeksplorasi sendiri konsep-konsep yang harus mereka kuasai, dan peserta didik aktif untuk bertanya dan berargumentasi melalui diskusi, juga dapat menggali konsep siswa sehingga dapat meningkatkan hasil belajar siswa. Pembelajaran berbasis masalah mengarahkan hampir seluruh siswa aktif dalam proses pembelajaran sehingga guru hanya berperan sebagai fasilitator dan siswa dapat terlihat lebih aktif dalam pembelajaran. Siswa yang tadinya pasif dalam pembelajaran dengan menerapkan model pembelajaran ini siswa menjadi bersemangat dan lebih fokus pada 
pembelajaran karena mereka terlibat langsung dengan tema yang dipelajari, dan harus menuangkan pengetahuan yang mereka miliki dalam bentuk mind map. Mind map yang mereka buat berisi konsep yang ditulis dan dihubungkan dengan warnawarna yang menarik menurut mereka, sehingga konsep yang ditulis lebih mudah diingat kembali. Para siswa dapat menguasai materi yang diajarkan sehingga hasil belajar pada kelas eksperimen lebih tinggi dibandingan kelas kontrol. Kelas kontrol menggunakan model pembelajaran berbasis masalah, sehingga ketika proses mengumpulkan jawaban mereka hanya membuat catatan biasa saja.

Berdasakan hasil analisis hampir seluruh indikator mengalami peningkatan penguasaan konsep, karena pada tahap ini siswa dituntut tidak hanya mengetahui dan mengingat suatu konsep tetapi juga harus dapat memahami materi apa yang sedang mereka pelajari dengan sendirinya mereka dapat mengaplikasikan apa yang telah mereka dapati. Menurut Tia Ghozwatul F (2017) model Problem Base Learning dengan strategi mind map dapat meningkatkan penguasaan konsep karena proses pembelajaran yang terjadi menimbulka dampak yang positif bagi siswa, dampak positif yang terjafi antara lain siswa menjadi lebih mandiri dan berani dalam mengemukakan pendapatnya.

Kemampuan berpikir kreatif siswa pada penelitian ini dijaring melalui tes dan ada penugasan mind map pada kelas eksperimen. Berpikir kreatif adalah memiliki ide-ide yang tidak biasa dan pemikiran inovatif, mampu menempatkan sesuatu bersama-sama dengan cara baru dan imajinatif. Berpikir kreatif melibatkan siswa dalam proses pembelajaran untuk menghasilkan dan menerapkan ide-ide baru dalam konteks tertentu, melihat situasi yang ada dengan cara yang baru, mengidentifikasi penjelasan alternatif, dan melihat atau membuat hubungan baru yang menghasilkan sesuatu yang positif. Dalam berpikir kreatif digunakan proses berpikir divergen, yaitu berpikir ke berbagai arah, sehingga menghasilkan berbagai macam jawaban atau alternatif penyelesaian. Proses berpikir divergen ini dituangkan dalam bentuk mind map sehingga membantu siswa berpikir secara ekspansif dan berpikir secara kreatif. Untuk menjadi kreatif maka perlu membebaskan imajinasi dan hal ini dapat dilakukan dengan menggunakan mind map.

Berdasarkan hasil pengamatan yang dilakukan pada saat penelitian, peneliti menemukan bahwa siswa merasa antusias dan senang saat membuat mind map. Artinya, penggunaan mind map dalam pembelajaran sangat menyenangkan dan dapat menumbuhkan minat belajar siswa. Sehingga siswa dapat membuat mind map sesuai dengan apa yang dipikirkannya dan memilih warna-warna yang mereka suka. Tujuannya adalah agar memudahkan mereka mengingat konsep atau informasi yang mereka peroleh. Hal ini yang menjadikan pembuatan dan peninjauan ulang catatan lebih menyenangkan. 
Penelitian ini bertujuan mengetahui peningkatan (N-gain) kemampuan berpikir kreatif yang diperoleh dari hasil bagi antara selisih skor postes dan pretes dengan selisih skor ideal dengan skor pretes. Berdasarkan hasil perhitungan N-gain kemampuan berpikir kreatif, kelas eksperimen yang memperoleh pembelajaran berbasis masalah dengan mind map mendapat nilai rata-rata $\mathrm{N}$-gain 0,79 lebih besar dari rata-rata $\mathrm{N}$-gain kelas kontrol yang menerapkan pembelajaran berbasis masalah memperoleh nilai rata-rat $\mathrm{N}$-gain 0,70 dimana kedua kelas memiliki klasifikasi sedang. Berdasarkan hasil uji hipotesis kemampuan berpikir kreatif siswa pada kelas eksperimen dan dengan kelas kontrol diperoleh nilai 0,013 (sign 2 tailed) $<0,05$. Maka H0 ditolak, artinya terdapat perbedaan peningkatan secara signifikan pada kelas eksperimen dan kelas kontrol.

Indikator kemamapuan berpikir kreatif yang pertama adalah berpikir asli (originality). Berdasarkan definisinya kemampuan berpikir asli (originality) menuntut siswa untuk memikirkan cara membuat kombinasi yang unik. Kemampuanberpikir asli (originality) merupakan inti dari pemikiran yang menghasilkan ide-ide unik yang tidak biasa. Penigkatan kemampuan berpikir lancar pada kelas eksperimen karena lancar dalam mengemukakan gagasan-gagasan dan lebih dapat melihat masalah dari sudut pandang yang berbeda. Tahapan-tahapan dalam pembelajaran berbasis masalah dengan mind map memungkinkan siswa lebih aktif dalam mengemukakakan gagasan untuk sama-sama menyelesaikan tugas dengan baik.

Indikator kemampuan berpikir kreatif lainnya adalah kemampuan berpikir memerinci (elaboration), indikator ini digunakan untuk mengembangkan atau memerinci gagasan secara lebih detail dan menarik. Peningkatan kemampuan ini karena suasana belajar dan rasa kebersamaan yang tumbuh dan berkembang diantara sesama anggota kelompok pada kelas eksperimen yang memmungkinkan siswa untuk mengerti dan memahami serta menguasai materi pelajaran dengan baik.

Keberhasilan pembelajaran berbasis masalah dengan mind map, selain tercermin dari hasil penguasaaan konsep dan kemampuan berpikir kreatif, juga dapat terlihat dari pernyataan angket pada tanggapan siswa terhadap pembelajaran berbasis masalah dengan mind map pada materi pencemaran lingkungan, sebanyak $79 \%$ siswa menyatakan model pembelajaran ini menarik. Ada $73 \%$ siswa menyatakan pembelajaran berbasis masalah dengan mind map membuat siswa lebih termotivasi untuk aktif belajar IPA. $71 \%$ siswa menyatakan pembelajaran berbasis masalah dengan mind map membuat siswa mengingat materi lebih baik.

Hasil penelitian baik secara keseluruhan maupun setiap indikator yang diajarkan terjadi peningkatan, baik itu untuk penguasaan konsep maupun kemampuan berpikir kreatif dengan menggunakan pembelajaran berbasis masalah dengan mind map. Pembelajaran berbasis masalah dengan mind map memiliki 
peranan penting dalam peningkatan hasil kemampuan penguasaan konsep maupun kemampuan berpikir kreatif. Oleh karena itu dengan pembelajaran berbasis masalah dengan mind map mampu meningkatkan penguasaan konsep siswa dan kemampuan berpikir kreatif pada materi pencemaran lingkungan.

Berdasarkan hal tersebut diatas dapatlah dipahami alasan mengapa penerapan model pembelajaran berbasis. Masalah berbantuan mind map dapat meningkatkan keterampilan berpikir kreatif siswa yang berimbas pada peningkatan hasil belajar. Karena dengan belajar dalam suasana yang menyenangkan dapat membuat siswa menjadi kreatif dan maksimal dalam mengeksplorasi pengetahuan yang sudah dimiliki sebelumnya dipadukan dengan tambahan pengetahuan yang baru dan dituangkan dalam bentuk maping, dimana maping mampu mengasah kemampuan kerja otak karena maping penuh dengan unsur kreativitas, selain itu pengetahuan yang sudah dibuat dalam bentuk maping lebih mudah untuk dipelajari kembali karena siswayang menemukan sendiri pengetahuannya tersebut. Berdasarkan pemaparan di atas, dapat disimpulkan bahwa model pembelajaran berbasis masalah dengan mind map lebih baik diterapkan untuk meningkatkan kemampuan berpikir kreatif dan penguasaan konsep dibandingkan model pembelajaran berbasis masalah.

\section{PENUTUP}

Berdasarkan penelitian yang telah dilakukan dapat disimpulkan bahwa terdapat perbedaan yang signifikan pada kemampuan berpikir kreatif dan penguasaan konsep yang dibelajarkan dengan model pembelajaran berbasis masalah dengan mind map dengan siswa yang dibelajarkan dengan model pembelajaran berbasis masalah.

Berdasarkan simpulan dalam penelitian ini, dapat diberikan saran bagi siswa, guru dan peneliti lainnya sebagai berikut: (1) Bagi siswa disarankan agar lebih membiasakan diri dengan pembelajaran berbasis masalah sehingga dapat secara mandiri dan aktif untuk memecahkan masalah dan menemukan sendiri pengetahuannya. (2) Bagi guru, agar memperhatikan masalah yang akan digunakan agar sesuai dengan materi dan kemampuan kognitif siswa dan lebih mengoptimalkan bagaimana cara membimbing siswa baik secara kelompok maupun individu tetang cara pembuatan mind map, sehinga dihasilkan mind map yang sesuai dengan tujuan yang telah ditetapkan (3) kepada peneliti yang lain agar melakukan penelitian sejenis lebih lanjut terhadap bagian-bagian sains yang lain untuk menguji efektivitas model pembelajaran berbasis masalah berbantuan mind map pada aspek yang lain. 


\section{REFERENSI}

Adodo, S O. (2013). Effect of Mind Mapping as a Self-Regulated learning Strategy on Students' Achievement in Basic Science ang Technology. Mediterranean Journal of Social Sciences, 4 (6), 163-172.

Dhindsa, H., Kasim, M., \&Anderson, O.R. (2011). Constructivist-Visual Mind Map teaching Approach and the Quality of Students" Cognitive Structures. J Sci Educ Technology, 20, 186-200.

Frankel, J.P. \& Wallen N.E. (2008). How to Design and Evaluate Research in Education. New York : Mc Graw - Hill Companies. Inc.

Long, D. \& Carlson, D. (2011). Mind the Map: How hinking aps Affect student Achievement. Mediteranian Journal of Social Science, 13 (2), 1-7.

Trilling, B., \& Fadel, C. (2009). 21st Century Skills: Learning for live in Our Times. San Francisco:Jossey bass, A willey imprint. 